\title{
Performance analysis of a Silicon PV module (100W) in outdoor conditions: Experimental and Simulation study
}

\author{
M.R.I. Ramadan, A.A. El-Sebaii, H.G. El-Gohary, A. Ibrahim*, \\ and A.M.A. Abdel-Dayem.
}

Physics Department, Faculty of Science, Tanta University, 31527, Tanta, Egypt

\begin{abstract}
In this paper, the incident solar radiation on horizontal and tilting surfaces was measured for a year using a pyranometer on the roof of Tanta University's Faculty of Science in Tanta city which is located at Latitude (30 41 ). The average daily global hourly solar radiation values on horizontal surfaces $(H)$ and the global hourly solar radiation values on inclined surfaces $\left(H_{t}\right)$ had been measured in the south direction of the sun for the meteorological variables. Miguel et al. correlation was used to determine hourly values of the beam and diffuse components of solar radiation (SR) from global solar irradiance. In order to attain the best solar module performance throughout the year, the solar energy devices must be tilted south with a tilting angle equal to Tanta city's latitude. The maximum value of $H_{t}$ was $1174.15 \mathrm{Wm}^{-2}$ in April and the minimum value of $H_{t}$ was $816.11 \mathrm{Wm}^{-2}$ in October. The performance of $100 \mathrm{~W}$ solar silicon photovoltaic $(P V)$ module in outdoor conditions can be studied by depending on the incident values of $H$ and $H_{t}$. The obtained results showed that the efficiencies of the $100 \mathrm{~W}$ solar PV module in winter, spring, summer and autumn were 4.29, 3.78, 7.56 and $4.58 \%$, respectively. The maximum power point $\left(P_{\max }\right)$ was calculated in July and its value was $45.98 \mathrm{~W}$ at solar noon and the minimum power point $\left(P_{\min }\right)$ was calculated in October with a value equal to $18.56 \mathrm{~W}$ at solar noon. Also, the short circuit current $\left(I_{s c}\right)$, the open-circuit voltage $\left(V_{o c}\right)$, the series resistance $\left(R_{s}\right)$, the shunt resistance $\left(R_{s h}\right)$, and other electrical properties help to identify the performance of the solar PV module had been measured. The calculated optimum load resistance $\left(R_{\text {Lmp }}\right)$ was 3.42, 3.88, 3.39, and 4.82 $\Omega$, in winter, spring, summer and autumn, respectively. Also, a simulation of three cases of solar photovoltaic systems to generate the electric power for applying the domestic utilization of these systems had been determined. This simulation depends on an application called SolarCT to calculate the requirements of the photovoltaic systems in El-Gharbia province had been used.
\end{abstract}

\section{Keywords}

Silicon PV module, I-V characteristics, Power calculations, Optimum load, Simulation.

\section{Paper information:}

Receive Date: 23 October 2021; Revise Date: 22 November 2021; Accept Date: 25 November 2021; Publish Date: 29 November 2021.

*Corresponding Author: ali.ibrahim1@ science.tanta.edu.eg 


\section{Introduction}

Life on the earth almost totally depends on the regular input of energy that is supplied by solar radiation [1,2]. Solar radiation may be converted to other forms of energy by several conversion processes $[3,4]$. Thermal conversion relies on the absorption of solar energy to heat a cold surface $[5,6]$. Photovoltaic conversion generates electrical power by the generation of electrical current as a result of a quantum mechanical process [7, 8]. Wind power and ocean energy conversion rely on atmospheric pressure gradients and oceanic temperature gradients to generate electrical power $[9,10]$. Solar radiation is produced as a result of a nuclear fusion process in the sun and the produced energy is called Solar Energy [11, 12]. Since ancient times, humans use solar energy in a range of ever-evolving technologies so, it becomes the most abundant alternative energy source in the world [13].

In 1839, Henri Becquerel made his first study on the Photovoltaic effect and its uses. He found that solar radiation can be converted to electricity based on the Photovoltaic effect. When two electrodes connected with a solid or liquid system, an electrical voltage emerged upon shining light onto this system. This process is defined as the Photovoltaic effect $[14,15]$. Some types of semiconductor materials can absorb a wide part of the solar radiation so; the Photovoltaic devices incorporate the P-n junction [40]. The electron-hole pairs which generate solar radiation are absorbed and reach the junction if their recommendation is prevented and they separated by an electric field [16]. The process of converting solar radiation to electricity is a very important application for solar energy so, it is called according to its effect on semiconductor materials. It is named Photovoltaic (abbreviated PV) [17].

PV systems are consisting of one or more PV panels, a battery storage unit, and DC/AC converter which is also called an inverter. Some PV systems may be small for a single user or to an isolated lamp or a weather device [18]. The generated electrical power can be stored, or connected to the electricity grid, or used directly in domestic applicants [19]. Two main types of solar PV systems are Standalone PV systems and grid-connected PV systems [19]. Standalone PV systems deliver power started from milliwatts to several kilowatts. Nowadays there are a lot of applications that depend on Standalone PV systems such as solar watches, solar calculators, systems of traffic controls, and more applications [20]. There is a type of PV system which connected to the general electricity grid with suitable PV inverters called grid-connected PV systems [21].

Analysis of single diode model of PV characteristics has been reported by "D. Revati and E. Natarajan [22]." The simulation and performance analysis of PV (I-V and P-V characteristics) was obtained by three different methods, such as Mathematical Modelling, Simscape Modelling, and Matlab coding by varying different solar radiation and temperature values depending on. From the simulation results, all three methods yield almost the same output [22].

Different PV types (mono-crystalline, polycrystalline) were tested under different shading rates by "Mahammed et al. [23]." The obtained IV characteristics had been treated by using Bishop Model which provides an accurate power losses prediction caused by different shading effects. The measured and estimated I-V characteristic plots illustrated a good agreement [23]. In this 
work, we had calculated $\left(\mathrm{R}_{\mathrm{Lmp}}\right)$ for a $100 \mathrm{~W}$ solar module in Tanta University. Then applying the obtained data to simulate the possibility of utilizing this data in a nearby community.

\section{Experimental}

The Eppley-Precision spectral Pyranometer had used to measure the solar radiation (SR) to count it. We used a SR meter depending on the particular sensitivity by watt per square meter unit [39]. The silicon PV module contains 36 series-connected solar cells and each cell has an area of 0.66 $\mathrm{m}^{2}$. The current and the voltage of the solar modules were measured using digital Multimeter DT9205A, Multimeter Fluke73 and Multimeter DT92205N. The variable load resistance is about $11.316 \mathrm{~K} \Omega$, which is divided into three resistances R1, R2 and R3. R1 and R2 are Nickel Chrome Wire. R1 is $29 \Omega$ with a diameter of $0.11 \mathrm{~cm}$ and $17 \mathrm{~m}$ in length. R2 is $177 \Omega$ with a diameter of $0.08 \mathrm{~cm}$ and $50 \mathrm{~m}$ length. R3 is $11.1 \mathrm{~K} \Omega$, H.TINSLEY\&CO.LTD. LONDON S.E.25, Type (5274-4D) [5].

\section{Results}

\section{Analysis of Solar Radiation Measurements.}

Hourly SR on the inclined surface had been studied in face South direction for defining 100W silicon PV module properties in air conditions around a whole year from January to December. The study did 4 times daily for 3 days monthly around the whole year. We chose one month for each season which are January, April, July and October. Figure (1) (a-d) shows the difference between $\mathrm{H}_{\mathrm{t}}$ and $\mathrm{H}$ for month in each season around a year.

It is observed that, in Fig. 1 (a) for January there was a difference between $\mathrm{H}_{\mathrm{t}}$ and $\mathrm{H}$. In the first run, which occurred in the period from $8 \mathrm{AM}$ to 10:30 AM the obtained values of solar radiation $\mathrm{H} \& \mathrm{H}_{\mathrm{t}}$ were identical especially during the period from 8 AM to 9 AM After that a change had occurred in values. The $\mathrm{H}_{\mathrm{t}}$ values were higher than $\mathrm{H}$ values. In the second run, which started from $11 \mathrm{AM}$ to 1:30 PM a big difference between the obtained values of the SR components. In the third run, which started from $2 \mathrm{PM}$ to 3:40 PM, $\mathrm{H}_{\mathrm{t}}$ values were higher than that of $\mathrm{H}$ with many values where in pre-end of the run the difference of values was small. In the last run of the day which started from 4 PM till the sunset at 5:10 PM the difference between $\mathrm{H}$ and $\mathrm{H}_{\mathrm{t}}$ was small. The explanation of that day results, when the sky is cloudy, the diffuse beam component will be increased which leads to increasing the values of $\mathrm{H}_{\mathrm{t}}$ and making a difference in the values of $\mathrm{H}[24]$.

In April as shown in Fig.1 (b), in the first run, which started from 8 AM to 10:30 AM. At 8 AM $\mathrm{H} \& \mathrm{H}_{\mathrm{t}}$ were identical but from 9 AM till the end of that run, a little difference occurred between them. In the second run, which started from 11 AM to 1:30 PM the difference which started in first run still occurred. It's noticed that there was no difference between $\mathrm{H} \& \mathrm{H}_{\mathrm{t}}$ in third run and fourth 
run, which occurred from 2 PM to 3:40 PM. And from 4 PM to 6:30 PM because of the cleanliness of the sky from any clouds.

In July as in Fig.1 (c), the difference between $\mathrm{H}_{\mathrm{t}}$ and $\mathrm{H}$ was very small. At the same time, it was noticed that the values of $\mathrm{H}$ were higher than the values of $\mathrm{H}_{\mathrm{t}}$. This phenomenon occurred in summer season only because the sky is clean from any clouds and the direct beam component has been increased which increases the values of $\mathrm{H}$ and it makes a difference in values of $\mathrm{H}_{\mathrm{t}}$ [25].

In October as in Fig.1 (d), it was observed that the first, third and fourth Runs were identical in values of solar radiation components. A significant difference occurred in Run 2 only since, the $\mathrm{H}_{\mathrm{t}}$ value was higher than the $\mathrm{H}$ value $\left(\mathrm{H}_{\mathrm{t}}>\mathrm{H}\right)$. As shown from Fig. (1) (a-d) we could conclude that the maximum value of $\mathrm{H}_{\mathrm{t}}$ had been obtained as $1174.15 \mathrm{Wm}^{-2}$ in April and in October, the minimum value of $\mathrm{H}_{t}$ had determined as $816.11 \mathrm{Wm}^{-2}$. The effective ratio of solar energy $\left(\mathrm{R}_{\mathrm{t}}\right)$ is the percentage of incident solar energy on a tilted surface to that on a horizontal surface [3] [5]. At solar noon, it was found that the percentage of $\left(\mathrm{R}_{\mathrm{t})}\right.$ in winter, spring, summer and autumn was $1.405,1.051,0.958$, and 1.183, respectively.

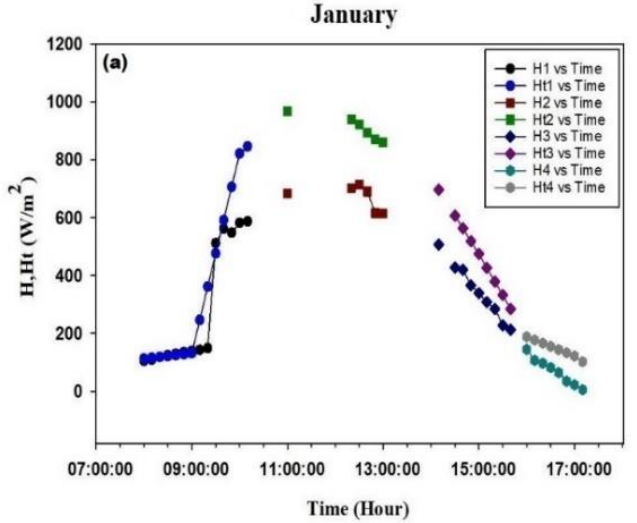

July

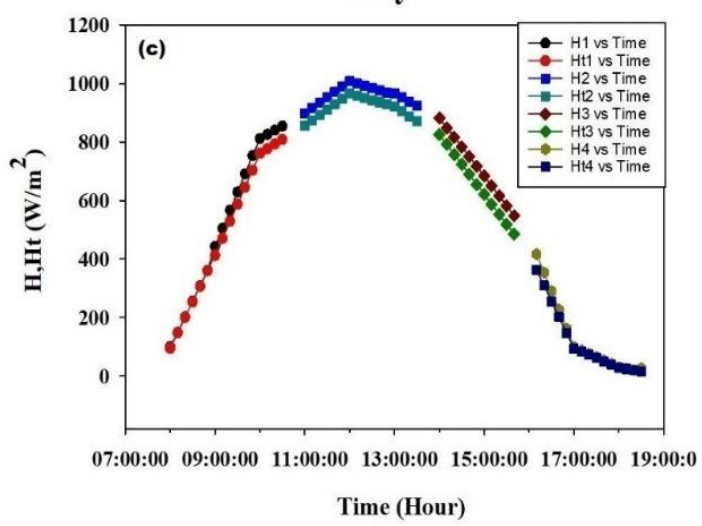

April

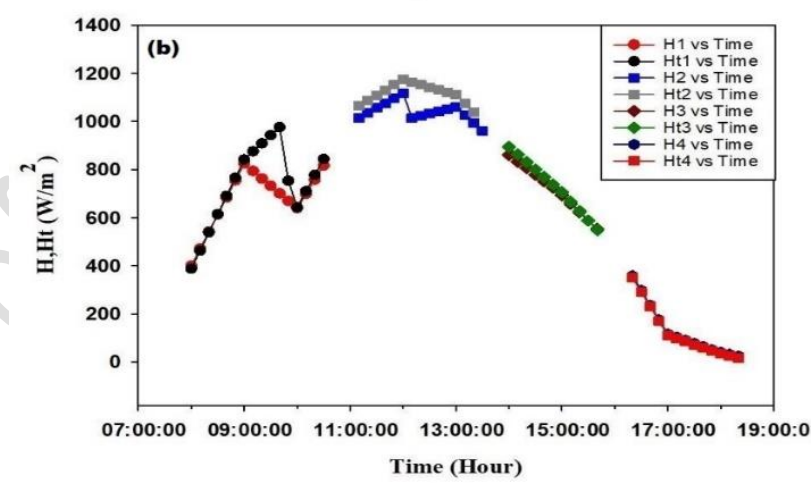

October

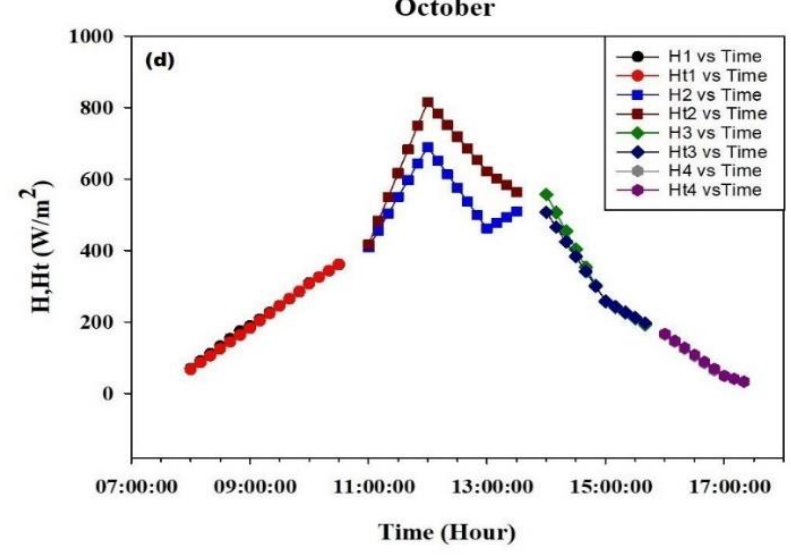

Figure (1): $\mathrm{H}_{\mathrm{t}}$ and $\mathrm{H}$ with time of the day in, (a) Winter, (b) Spring, (c) Summer and (d) Autumn.

\section{Analysis of Outdoor Measurements for a silicon PV solar module}




\subsection{Current-Voltage Characteristics.}

During this section we obtained the electrical properties of the $100 \mathrm{~W}$ silicon PV module around a year. The PV modules are affected by the seasonal temperature variations and spectral irradiance. $I_{s c}$ and $V_{o c}$ are used to analyze the modules output for a year. From figure (2) (a) it has been found that $I_{s c}$ values increase in Summer and Spring and decrease in Winter and Autumn. It has been seen

that

$\mathrm{I}_{\mathrm{sc}}$ values increase slightly with increasing temperature and decrease with decreasing temperature which is season-dependent [40]. In figure (2) (b) it has been seen that $\mathrm{V}_{\mathrm{oc}}$ values decrease in Summer and Spring and increase in Winter and Autumn, it is evident that $\mathrm{V}_{\mathrm{oc}}$ values decrease with increasing temperature and increase with decreasing temperature [26].
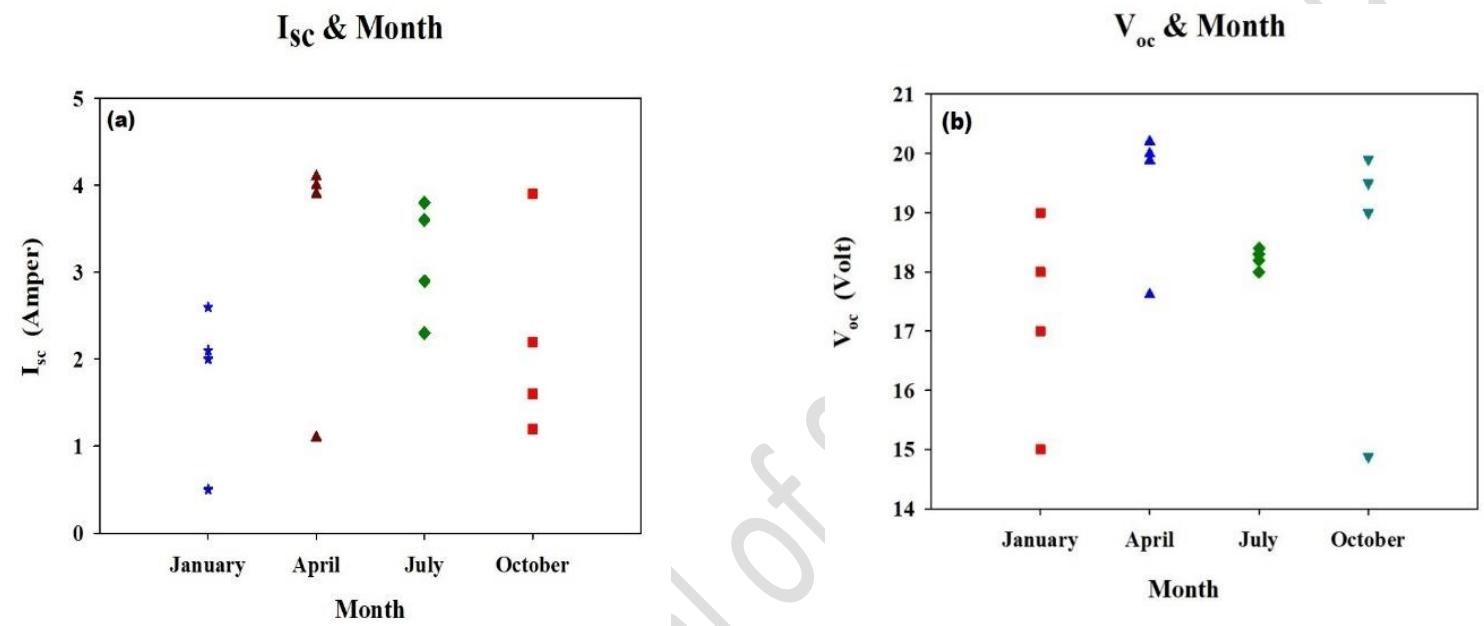

Figure (2): (a) Short circuit current of 100W silicon PV module for one year, (b) Open circuit voltage of $100 \mathrm{~W}$ silicon PV module for one year.
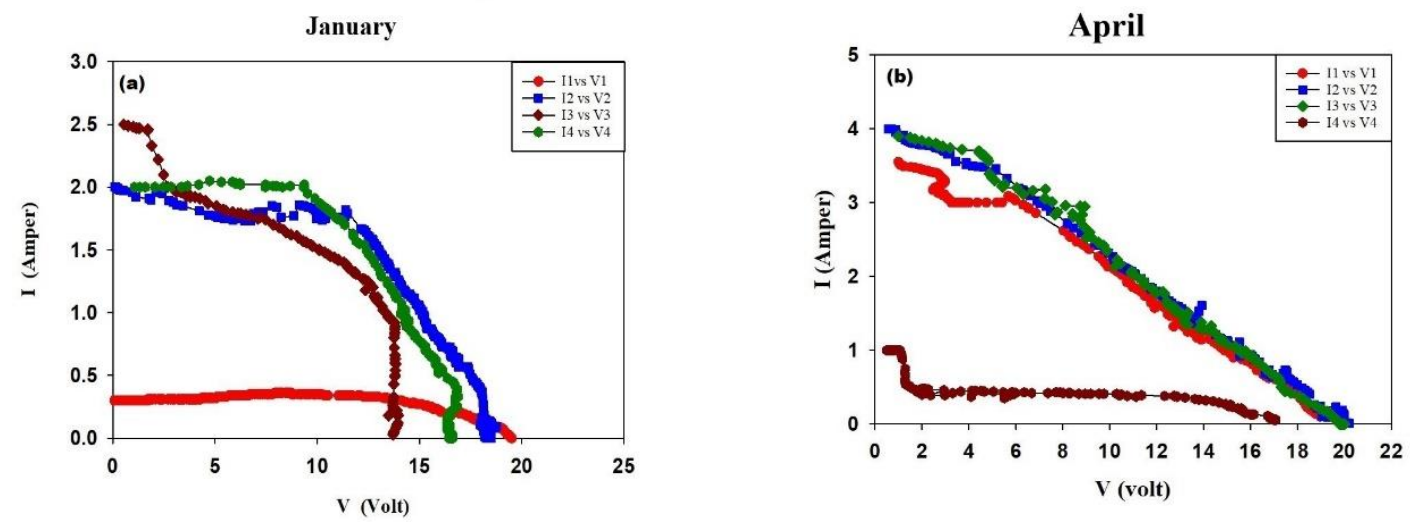

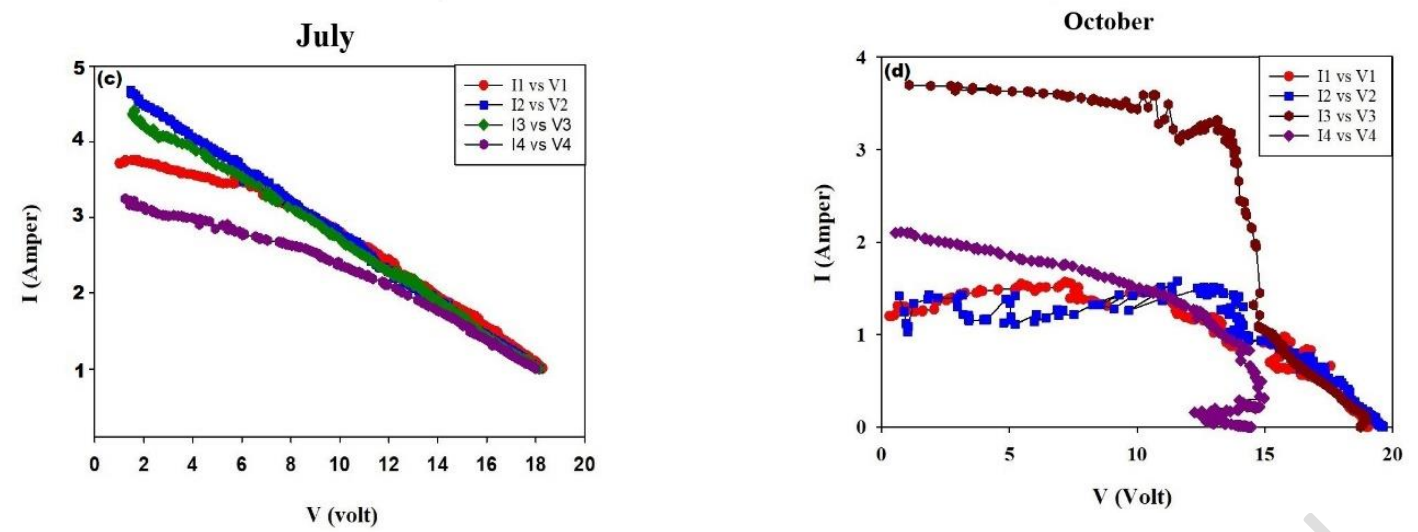

Figure (3): I-V characteristic curves of silicon PV module of a day in (a) Winter, (b) Spring, (c) Summer and (d) Autumn.

The measurements of IV characteristics are affected by the weather conditions and the variations of the temperature. So, it was important to record the changes in I and V in each day for each month in all seasons around a year and draw the characteristic curves for each season as shown in Figure 3 (a-d). By using the I-V characteristic curves and equations (1) and (2) the $R_{s}$ and $R_{s h}$ for PV module had been calculated as listed in Table (1):

$$
\begin{aligned}
& \frac{d I}{d V} \mid\left[I=I_{s c} \& V=0\right]=-\frac{1}{R_{s}} \\
& \frac{d I}{d V} \mid\left[I=0 \& V=V_{o c}\right]=-\frac{1}{R_{s h}}
\end{aligned}
$$

Table (1): Values of $R_{s}, R_{s h}$ around the year.

\begin{tabular}{|c|c|c|c|}
\hline Month & No of Run & $\mathrm{R}_{\mathrm{s}}(\Omega)$ & $\mathrm{R}_{\mathrm{sh}}(\Omega)$ \\
\hline \multirow{3}{*}{ January } & Run 1 & 2.579 & 38.912 \\
\hline \multirow{3}{*}{ April } & Run 2 & 0.510 & 5.692 \\
\cline { 2 - 4 } & Run 3 & 0.459 & 4.218 \\
\cline { 2 - 4 } & Run 4 & 0.505 & 6.077 \\
\hline \multirow{3}{*}{ July } & Run 1 & 0.312 & 4.435 \\
\hline & Run 2 & 0.433 & 3.831 \\
\hline & Run 3 & 0.47 & 2.948 \\
\hline \multirow{5}{*}{ October } & Run 4 & 0.483 & 40.40 \\
\hline & Run 1 & 0.315 & 3.977 \\
\hline & Run 2 & 0.332 & 5.593 \\
\hline & Run 3 & 0.369 & 3.405 \\
\hline & Run 4 & 0.434 & 26.401 \\
\hline & Run 1 & 0.462 & 7.578 \\
\hline & Run 2 & 0.302 & 8.763 \\
\hline & Run 3 & 0.295 & 4.516 \\
\hline & Run 4 & 0.526 & 7.271 \\
\hline
\end{tabular}




\subsection{Power - Voltage Characteristics.}

The electrical parameters of silicon PV module are very important to evaluate the performance of solar silicon PV module.one of these parameters is Power-Voltage characteristic, which depends on IV measurements for solar silicon PV module. Figure (4) (a-d) illustrates the PV characteristic curves of 100W solar silicon PV module for one-year. From Figure (4) (a) it had observed that the first run from 8 AM to 10:30 AM the $\mathrm{P}_{\max }$ value was $4.39 \mathrm{~W}$ and it increased in the second run which started from 11 AM to 1:30 PM to be $20.94 \mathrm{~W}$. In the third run, it had reached to $25.95 \mathrm{~W}$ which started from $2 \mathrm{PM}$ to 3:40 PM finally, in the last run which occurred from 4 PM to 5:10 PM the $\mathrm{P}_{\max }$ value was $17.54 \mathrm{~W}$.

In Spring, the $\mathrm{P}_{\max }$ value in first run was $21.064 \mathrm{~W}$, in the second run it was $24.88 \mathrm{~W}$, in the third and fourth run the $\mathrm{P}_{\max }$ value was $26.12 \mathrm{~W}$ and $9.77 \mathrm{~W}$, respectively as noticed in Fig. (4) (b).

In Fig. (4) (c) which represents the summer season, it was found that the $P_{\max }$ value in first and second run was $14.55 \mathrm{~W}$ and $45.98 \mathrm{~W}$, respectively while in the third and fourth run were 19.08 $\mathrm{W}$ and $14.11 \mathrm{~W}$, respectively. Finally, Fig. (4) (d) which represent the Autumn season the $\mathrm{P}_{\max }$ value in the first, second, third and fourth runs were $17.67 \mathrm{~W}, 18.56 \mathrm{~W}, 16.12 \mathrm{~W}$ and $14.14 \mathrm{~W}$, respectively. From Figure (4) (a-d), it could be determined the $P_{\max }$, the maximum voltage $\left(\mathrm{V}_{\max }\right)$ and maximum current $\left(I_{\max }\right)$. And from Figure (2) (a-b), we were determined $I_{s c}$ and $V_{o c}$ [27].So, the Fill Factor and The Efficiency could be calculated by depending on the following equations (3) and (4) [28].

$F F=\frac{\operatorname{Vmax} * \operatorname{Imax}}{V_{o c} * I_{s c}}$

$\mathrm{\eta}=\frac{\mathrm{P}_{\mathrm{R}}}{\mathrm{P}_{\mathrm{in}}}=\frac{F F * V_{o c} * I_{S C}}{A * H}$

Where $P_{\text {in }}=A * H,[38]$. Table (2) shows the measured values of $I_{\max }, V_{\max }, I_{s c}, V_{o c}, H, F . F$ and $\eta$ at solar noon for $100 \mathrm{~W}$ solar silicon PV module around one year.

Table (2): Calculated values for silicon PV module (100W) at solar noon.

\begin{tabular}{|c|c|c|c|c|c|c|c|}
\hline & $\mathrm{I}_{\max }(\mathrm{A})$ & $\mathrm{V}_{\max }(\mathrm{V})$ & $\mathrm{I}_{\mathrm{sc}}(\mathrm{A})$ & $\mathrm{V}_{\text {oc }}(\mathrm{V})$ & $\mathrm{H}\left(\mathrm{W} / \mathrm{m}^{-2}\right)$ & $\mathrm{F} . \mathrm{F}$ & $\eta(\%)$ \\
\hline Winter & 1.88 & 11.14 & 2.5 & 19.9 & 737 & 0.42 & 4.29 \\
\hline Spring & 2.4 & 10.37 & 4 & 20 & 998 & 0.31 & 3.78 \\
\hline Summer & 3.46 & 13.29 & 3.8 & 18.2 & 914 & 0.66 & 7.56 \\
\hline Autumn & 1.49 & 12.46 & 1.6 & 19 & 618 & 0.61 & 4.58 \\
\hline
\end{tabular}


The values of $\mathrm{P}_{\max }$ had been occurred in Spring and Summer $24.88 \mathrm{~W}$ and $45.98 \mathrm{~W}$, respectively while the values of $\mathrm{P}_{\max }$ had been located in Winter and Autumn $20.94 \mathrm{~W}$ and $18.56 \mathrm{~W}$, respectively. For this silicon PV module, it has been found that the weather temperature and incident SR are very important parameters [29]. So, the better efficiencies were found in Spring and Summer while small efficiencies were in Autumn and Winter [30,31].
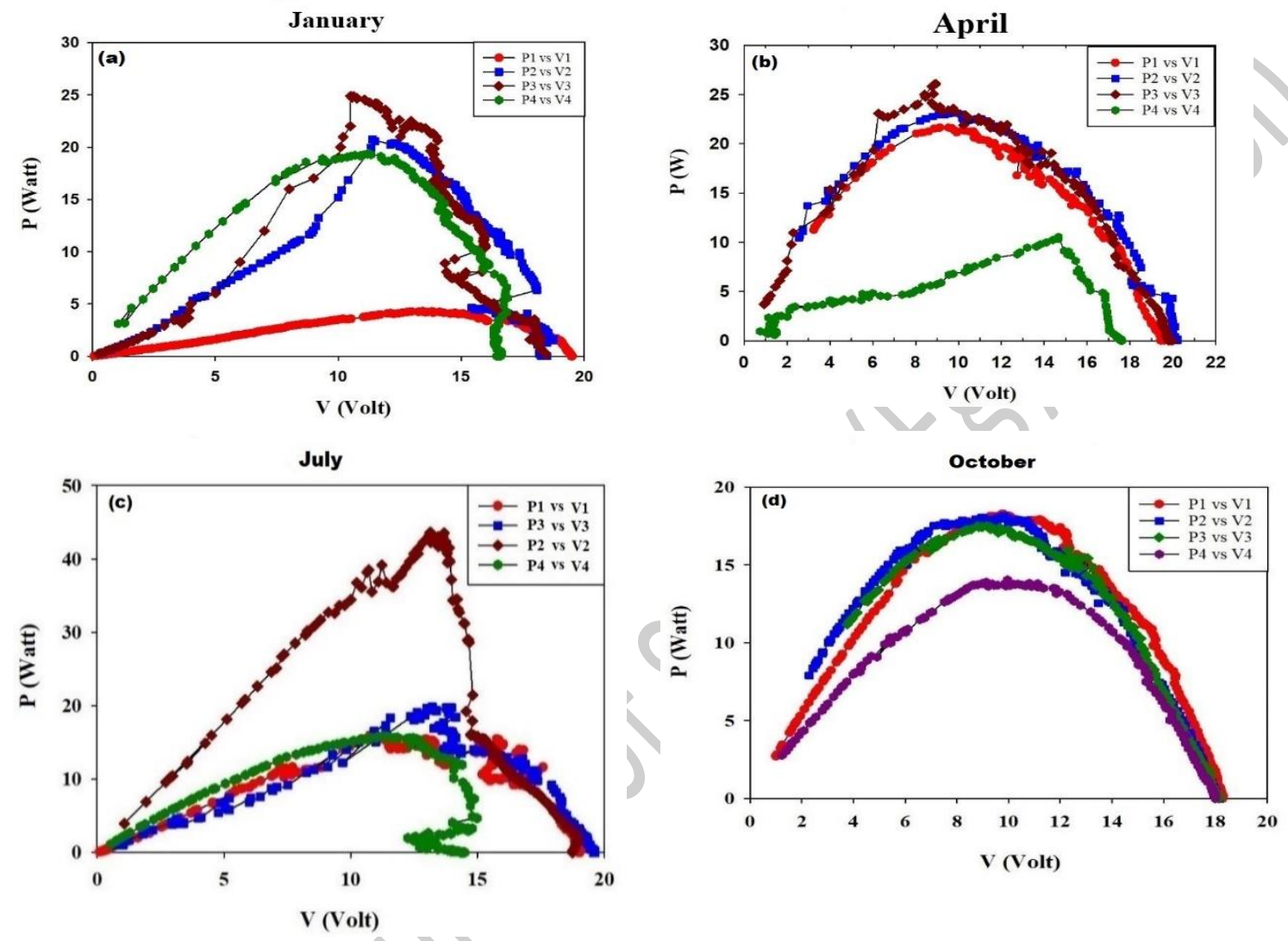

Figure (4): P-V characteristic curves of silicon PV module of a day in (a) Winter, (b) Spring, (c) Summer and (d) Autumn.

\section{Load resistance calculations.}

We utilize an equation that is the most generic equation to compute the $\mathrm{R}_{\mathrm{Lmp}}$ value $[32,33]$.

$$
R_{L m p}=-\left(\frac{V_{m}}{I_{m}}\right)=R_{S}+\frac{R_{s h}}{\left\langle\left(I_{o} \frac{R_{S h}}{V_{t h}}\right) \exp \left\{\left(\frac{V_{m}-I_{m} R_{S}}{V_{t h}}\right)\right\}+1\right\rangle}
$$

Where $I_{0}$ is the reverse saturation current $[35,36]$. By using the data which measured around year, we determine the thermal voltage $\left(\mathrm{V}_{\text {th) }}\right.$ from the equation $(6)[37,38]$

$$
V_{t h}=\frac{n K T}{q}
$$


To identify $I_{o}$, we need to draw a relationship between $V_{o c}$ and $L n\left(I_{s c}\right)$ and determine $I_{o}$ from the results of the plot according to the following equations $[39,40]$

$$
\begin{aligned}
& V_{o c}=\frac{n K T}{q}\left\{\ln I_{s c}-\ln I_{o}\right\} \\
& n=\operatorname{grad} * \frac{K T}{q} \\
& \ln I_{o}=-Y *\left[\frac{n K T}{q}\right]
\end{aligned}
$$

Table (3): $\mathrm{n}$ and $\mathrm{I}_{\mathrm{o}}$ values of the monocrystalline silicon PV module.

\begin{tabular}{|c|c|c|c|c|}
\hline & Slope $(\Omega)$ & $n$ & cutting part $(\mathrm{V})$ & $\mathrm{I}_{\mathrm{o}}(\mathrm{A})$ \\
\hline January & 4.7014 & 188.22 & 11.542 & $85 \times 10^{-3}$ \\
\hline April & 2.8531 & 112.373 & 15.903 & $3.799 \times 10^{-3}$ \\
\hline July & 2.3821 & 90.919 & 15.579 & $1.436 \times 10^{-3}$ \\
\hline October & 3.5865 & 138.956 & 16.447 & $102 \times 10^{-4}$ \\
\hline
\end{tabular}

Figure (5) illustrates the relation between $\mathrm{V}_{\mathrm{oc}}$ and $\mathrm{Ln}\left(\mathrm{I}_{\mathrm{sc}}\right)$ and from the plots we calculated the slope and the cutting part, and by its values we determined $\mathrm{n}$ and $\mathrm{I}_{0}$ as listed in the Table (3). We could determine $\left(\mathrm{R}_{\mathrm{Lmp}}\right)$ according to equation (5) and the results of these calculations are summarized in Table (4).

Table (4): Calculation of $\mathrm{R}_{\mathrm{Lmp}}(\Omega)$ in every run around year of a monocrystalline silicon PV module.

\begin{tabular}{|c|c|c|c|c|}
\hline Run / Month & January & April & July & October \\
\hline Run 1 & 4.0124 & 4.1132 & 5.9442 & 6.0255 \\
\hline Run 2 & 3.4292 & 3.8876 & 3.3993 & 4.8204 \\
\hline Run 3 & 3.1159 & 3.2605 & 3.4726 & 3.9958 \\
\hline Run 4 & 3.4441 & 4.3598 & 5.7206 & 5.8692 \\
\hline
\end{tabular}
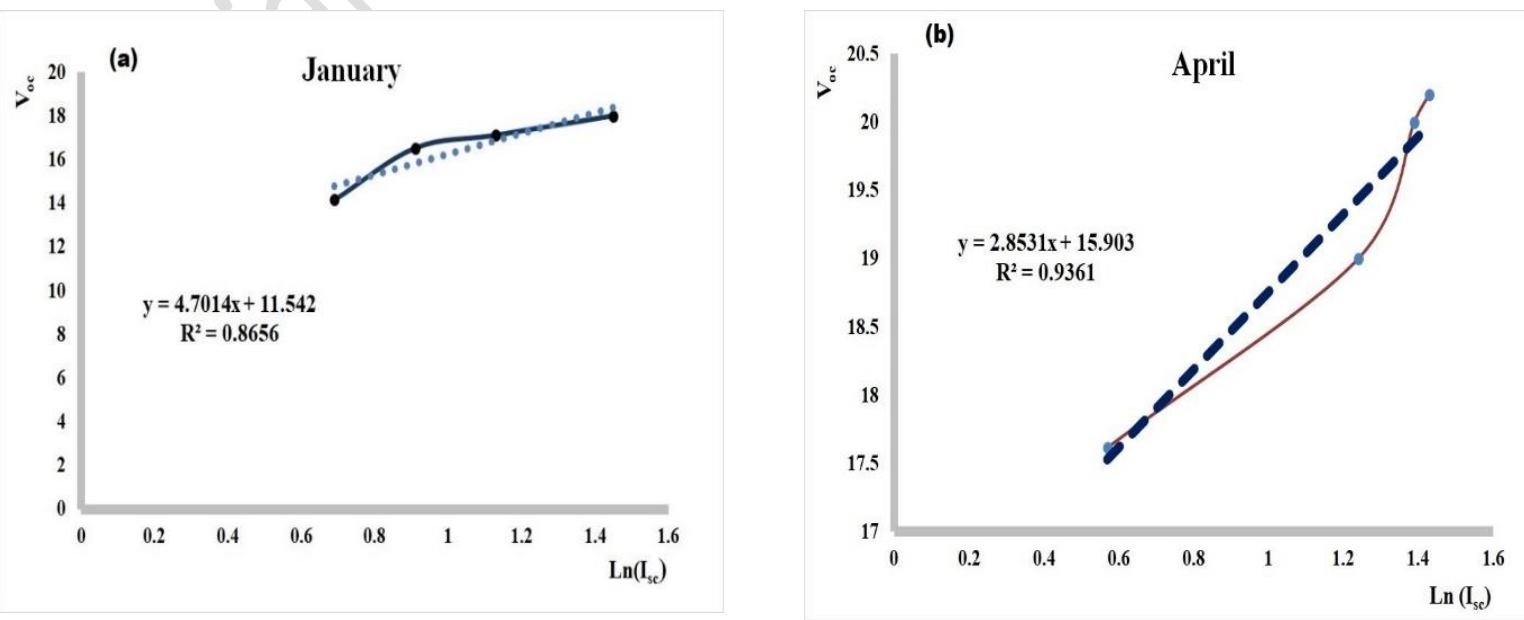

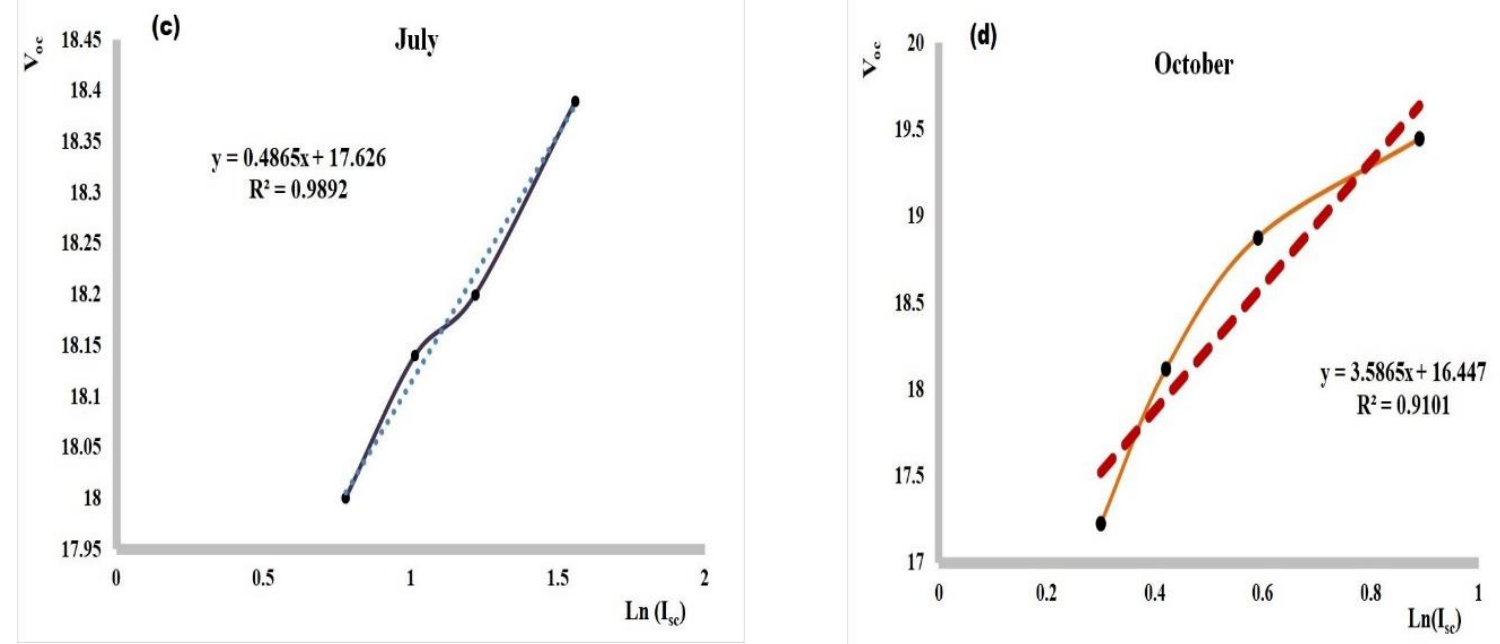

Figure (5): $\mathrm{V}_{\mathrm{oc}} \& \mathrm{Ln}\left(\mathrm{I}_{\mathrm{sc}}\right)$ characteristic curves of silicon PV module of a day in (a) Winter, (b) Spring, (c) Summer and (d) Autumn.

\section{Standalone solar Photovoltaic systems simulation}

\subsection{A Simple House}

In this case, A solar PV non-tracking system has been simulated to generate electrical power for a simple house for a husband and wife. This house is located in Tanta city and consists of two rooms, a living room, a hall, a kitchen, and a bathroom. The load requirements for this house are viewed in Table (5).

Table (5): Electrical power consumption per day for a simple house.

\begin{tabular}{|c|c|c|c|c|c|}
\hline $\begin{array}{c}\text { Electrical load } \\
\text { And Capacity (W) }\end{array}$ & Quantity & $\begin{array}{l}\text { Power } \\
\text { (W) }\end{array}$ & $\begin{array}{l}\text { Hours per Day } \\
\text { (hr) }\end{array}$ & $\begin{array}{l}\text { Total consumption } \\
\text { (W) }\end{array}$ & $\begin{array}{l}\text { Consumption } \\
\text { (KW h) }\end{array}$ \\
\hline Lamps (12W) & 10 & 120 & 5 & 600 & 0.6 \\
\hline Fridge $(200 \mathrm{~W})$ & 1 & 200 & 24 & 4800 & 4.8 \\
\hline $\begin{array}{l}\text { Washing \& Drying } \\
\text { machine }(800 \mathrm{~W})\end{array}$ & 1 & 800 & 0.5 & 400 & 0.4 \\
\hline Iron $(800 \mathrm{~W})$ & 1 & 800 & 0.25 & 200 & 0.2 \\
\hline Laptop (40W) & 1 & 40 & 6 & 240 & 0.24 \\
\hline $\begin{array}{c}\text { Mobile } \\
\text { Charger(5W) }\end{array}$ & 2 & 10 & 3 & 30 & 0.03 \\
\hline Fan $(40 \mathrm{~W})$ & 4 & 160 & 4 & 640 & 0.64 \\
\hline $\begin{array}{l}\text { LCD TV } 42 \text { inches } \\
\qquad(150 \mathrm{~W})\end{array}$ & 1 & 150 & 6 & 900 & 0.9 \\
\hline \multicolumn{5}{|c|}{ Electrical power consumption per day } & $7.81 \mathrm{KW} \mathrm{h}$ \\
\hline
\end{tabular}


The solar array is mounted on the roof of the house in the South direction of the sun with tilted angle $\left(30^{\circ} 68^{\circ}\right)$ to the horizontal. The amount of power needed along the day is equal to 7810 $\mathrm{W} / \mathrm{h}$. The system has a loss during the installation of any electrical system of its power nearly $10 \%$ of the required power. So, the total consumption power is calculated as: -

$$
\begin{gathered}
\text { Total consumption power }=\text { Electrical power }+ \text { loss percentage } \\
=7810+\{7810 * 10 \%\}=8591 \mathrm{Wh}
\end{gathered}
$$

The peak hours of sunshine in Tanta are $5 \mathrm{hrs}$ and 30 minutes per a day in the Summer season and in the winter season the peak hours of sunshine in Tanta are $4 \mathrm{hrs}$. And the system can depend on its storage $24 \mathrm{hrs}$. without charging by solar radiation. According to these conditions the power per hour needed is calculated

$$
\begin{aligned}
\text { Power per hour }= & \frac{\text { Total consumption power }}{\text { No of peak hours }} \\
& =\frac{8591}{5: 30}
\end{aligned}
$$

$=1557.28 \mathrm{Wh}$ in the summer season.

$$
\begin{aligned}
& \text { Power per hour }= \frac{\text { Total consumption } \text { power }}{\text { No of peak hours }} \\
&=\frac{8591}{4}
\end{aligned}
$$

$=2147.7 \mathrm{Wh}$ in the winter season.

So, the number of needed solar panels can be calculated according to:

$$
\begin{aligned}
& \text { Number of solar panels }=\frac{\text { Power per hour }}{\text { the size of solar panel }} \\
& =\frac{1562}{500} \quad \text { or } \quad=\frac{2147.7}{500}
\end{aligned}
$$

$=4$ panels in the summer or 5 panels in the winter.

To calculate the number of required batteries we depend on our calculations on system voltage of inverter which is equal to $48 \mathrm{~V}$ and the depth of battery discharging percentage which is equal to $75 \%$.

The Amp of battery is calculated as following: -

Amp of battery $=\frac{\text { Total Consumption power } * \text { hours without charging }}{\text { system inverter voltage } * \text { discharging percentage }}$ 


$$
\begin{gathered}
\qquad \frac{8591 * 24}{48 * 75 \%} \\
=238.6 \mathrm{Amp} \\
\text { No of batteries }=\frac{\text { Amp of battery }}{\text { battery capacity }} \\
=\frac{238.6}{100} \\
=3 \text { Batteries }
\end{gathered}
$$

Some of the appliances need more power from ( 3 to 10 times) when start running for the first 5 or 10 seconds so we should care to this information in the calculation of the inverter size. So, the inverter size could be obtained from: -

$$
\begin{aligned}
& \text { Inverter size }=\text { Power of appliances } \times 20 \% \text { additional power } \\
& \qquad \begin{aligned}
= & 2280 * 20 \% \\
& =3283 \mathrm{Watt}
\end{aligned}
\end{aligned}
$$

The controller size calculated from the following equation

$$
\begin{aligned}
\text { Controller size } & =\left\{\text { No of solar panels } \times \mathrm{I}_{s c}\right\} \times 30 \% \text { Additional factor } \\
& =[4 * 13.5] * 30 \% \text { or }[5 * 13.5] * 30 \%
\end{aligned}
$$

$=71$ Amp in the summer or 88 Amp in the winter.

When we studied the load requirements of a house using the solar PV system side by side to the local electrical grid (on grid), we don't need to use the electrical batteries. The Solar PV system will consist of solar panels and an inverter. The user will depend on the solar system within the daylight hours only to apply its electrical requirements and will use the local electrical gride during the night hours. By using the solar system its electrical bill will decrease by the time [41-44]. All calculations of the solar system on the last part (off gride) will use on this part without using the solar batteries. The cost of using the solar PV system side by side to the local electrical grid on grid and use 4 solar panels each panel has power $500 \mathrm{~W}$, an inverter and connecting wires and cables is 43000 LE [34].

\subsection{The solar energy research lab}

A solar PV non-tracking system has been simulated to generate electrical power for the solar research laboratory in the Physics Department, Faculty of Science, Tanta University. The load requirements for this lab. are summarized in Table (6).

Table (6): Electrical power consumption per day for the solar energy research Lab. 


\begin{tabular}{|c|c|c|c|c|c|}
\hline $\begin{array}{l}\text { Electrical load } \\
\text { and Capacity (W) }\end{array}$ & Quantity & $\begin{array}{l}\text { Power } \\
\text { (W) }\end{array}$ & $\begin{array}{l}\text { Hours per Day } \\
\text { (hr) }\end{array}$ & Total consumption (W) & $\begin{array}{l}\text { Consumption } \\
\text { (KW h) }\end{array}$ \\
\hline Lamps (12W) & 28 & 336 & 5 & 1680 & 1.68 \\
\hline Router (200W) & 1 & 200 & 5 & 1000 & 1 \\
\hline PC $(100 W)$ & 2 & 200 & 5 & 1000 & 1 \\
\hline Fan $(40 \mathrm{~W})$ & 4 & 160 & 5 & 800 & 0.8 \\
\hline \multicolumn{5}{|c|}{ Electrical power consumption per day } & $4.48 \mathrm{KWh}$ \\
\hline
\end{tabular}

The amount of power needed along the day equals to $4480 \mathrm{Wh}$. As Known that the system has a loss during the installation of any electrical system of its power nearly $10 \%$ of the required power. So, the total consumption power is calculated as: -

$$
\begin{aligned}
& \text { Total consumption power }= \\
& \qquad \begin{aligned}
=4480 & +\{4480 * 10 \%\} \\
& =4928 \mathrm{Wh}
\end{aligned}
\end{aligned}
$$

The peak hours of sunshine in Tanta are $5 \mathrm{hrs}$. and 30 minutes at the day. And the system can depend on its storage 24 hours without charging by solar radiation. According to these conditions the power per hour which needed is calculated by: -

$$
\begin{aligned}
\text { Power per hour }= & \frac{\text { Total consumption power }}{\text { No of peak hours }} \\
& =\frac{4928}{5.5} \\
& =896 \mathrm{Wh}
\end{aligned}
$$

So, the number of needed solar panels can be calculated according to: -

$$
\begin{aligned}
& \text { Number of solar panels }=\frac{\text { Power per hour }}{\text { the size of solar panel }} \\
& \qquad=\frac{896}{500} \\
& =2 \text { solar panels. }
\end{aligned}
$$


To calculate the number of required batteries we depend on our calculations on system inverter voltage which equals $48 \mathrm{~V}$ and the depth of battery discharging percentage which equals $75 \%$.

The Amp of battery is calculated as following: -

$$
\begin{aligned}
& \text { Amp of battery }=\frac{\text { Total Consumption power } * \text { hours without charging }}{\text { system inverter voltage } * \text { discharging percentage }} \\
& =\frac{4928 * 24}{48 * 75 \%} \\
& =136.9 \mathrm{Amp} \\
& \text { No of batteries }=\frac{\text { Amp of battery }}{\text { battery capacity }} \\
& =\frac{136.9}{100} \\
& =2 \text { Batteries }
\end{aligned}
$$

Some of the appliances need more power (3 to 10 times) when start running for the first 5 or 10 seconds so we should care to this information in the calculation of the inverter size.

Inverter size $=$ Power of appliances $\times 20 \%$ additional power

$$
\begin{aligned}
& =896 * 20 \% \\
& =1290 \mathrm{Watt}
\end{aligned}
$$

The controller size calculated from the following equation: -

Controller size $=\left\{\right.$ No of solar panels $\left.\times \mathrm{I}_{s c}\right\} \times 30 \%$ Additional factor

$$
\begin{gathered}
=[2 * 13.5] * 30 \% \\
=36 \mathrm{Amp} .
\end{gathered}
$$

\subsection{Physics Department}

A solar PV non-tracking system has been simulated to generate electrical power for the Physics Department, Faculty of Science, Tanta University. The load requirements for the Physics Department will contain department lighting, its corridors, faculty members' rooms, department administration, textbook distribution offices, and the department's bathrooms only. The requirements of electrical power are listed in Table (7).

Table (7): Electrical power consumption per day for the physics department. 


\begin{tabular}{|c|c|c|c|c|c|}
\hline $\begin{array}{l}\text { Electrical load } \\
\text { And Capacity (W) }\end{array}$ & Quantity & $\begin{array}{l}\text { Power } \\
\text { (W) }\end{array}$ & $\begin{array}{l}\text { Hours per } \\
\text { Day } \\
\\
\quad(h r)\end{array}$ & $\begin{array}{l}\text { Total consumption } \\
\text { (W) }\end{array}$ & $\begin{array}{l}\text { Consumption } \\
\text { (KW h) }\end{array}$ \\
\hline Lamps (12W) & 210 & 2520 & 5 & 12600 & 12.6 \\
\hline PC $(100 W)$ & 37 & 3700 & 5 & 18500 & 18.5 \\
\hline Fan (40W) & 45 & 1800 & 5 & 9000 & 9 \\
\hline Fridge $(200 \mathrm{~W})$ & 15 & 3000 & 24 & 72000 & 72 \\
\hline \multicolumn{5}{|c|}{ Electrical power consumption per day } & $112.1 \mathrm{KW} \mathrm{h}$ \\
\hline
\end{tabular}

The solar array is located on the roof of the Faculty of Science, Tanta University in face south. The amount of power needed along the day equals $112.1 \mathrm{KWh}$. The system has a loss during the installation of any electrical system of its power nearly $10 \%$ of the required power. So, the total consumption power is calculated as:

$$
\begin{aligned}
& \text { Total consumption power }=\text { Electrical power }+ \text { loss percentage } \\
& =112100+\{112100 * 10 \%\} \\
& =123310 \mathrm{~W}=123.31 \mathrm{KWh}
\end{aligned}
$$

The peak hours of sunshine in Tanta are $5 \mathrm{hrs}$. and 30 minutes at the day. And the system can depend on its storage 24 hours without charging by solar radiation. According to these conditions the power per hour which needed is calculated

$$
\begin{aligned}
\text { Power per hour }= & \frac{\text { Total consumption power }}{\text { No of peak hours }} \\
& =\frac{123310}{5.5} \\
& =22352.27 \mathrm{Wh}
\end{aligned}
$$

So, the number of needed solar panels can be calculated according to:

$$
\begin{gathered}
\text { Number of solar panels }=\frac{\text { Power per hour }}{\text { the size of solar panel }} \\
=\frac{22352.27}{500}=45 \text { solar panels }
\end{gathered}
$$

To calculate the number of required batteries we depend on our calculations on system inverter voltage which equal to $48 \mathrm{~V}$ and the depth of battery discharging percentage which equal to $75 \%$.

The Amp of battery is calculated as following: - 


$$
\begin{gathered}
\text { Amp of battery }=\frac{\text { Total Consumption power } * \text { hours without charging }}{\text { system inverter voltage } * \text { discharging percentage }} \\
\qquad=\frac{123310 * 24}{48 * 75 \%}=3425.3 \mathrm{Amp} .
\end{gathered}
$$

No of batteries $=\frac{\text { Amp of battery }}{\text { battery capacity }}==\frac{3425.3}{100}=35$ batteries

Some of the appliances need more power from ( 3 to 10 times) when start running for the first 5 or 10 seconds so we should care to this information in the calculation of the inverter size.

$$
\text { Inverter size }=\text { Power of appliances } \times 20 \% \text { additional power }
$$

$$
=11020 * 20 \%=15868 \mathrm{~W}
$$

The controller size calculated from the following equation: -

Controller size $=\left\{\right.$ No of solar panels $\left.\times \mathrm{I}_{s c}\right\} \times 30 \%$ Additional factor

$$
=[45 * 13.5] * 30 \%=790 \mathrm{Amp} \text {. }
$$

\section{Conclusion:}

In this work, the global SR was measured on a horizontal plane, while radiation on tilted surfaces was calculated by means of empirical models. Computer programs had been prepared for calculating the value of $\left(\mathrm{H}_{\mathrm{t}}\right)$ in the south direction of the sun for a whole one year. The maximum value of $\mathrm{H}_{\mathrm{t}}$ in face south was in April and the minimum value was in October. The PV module efficiency was strongly dependent on the seasons of the year. Also, all PV module electrical characteristics were depended on time of measurement and weathering conditions. The $\mathrm{P}_{\max }$ value was obtained in July at solar noon while, the $\mathrm{P}_{\min }$ value was calculated in October. $\mathrm{R}_{\mathrm{Lmp}}$ values for the solar PV module during one year in winter, spring, summer and autumn at solar noon were calculated. Finally, a simulation of three cases of solar PV systems to generate the electric power for applying as a domestic utilization of these systems had been carried out. Since, depending on an application called Solar CT the requirements of the photovoltaic systems in El-Gharbia province had been calculated.

\section{Declaration of Conflicting Interests}

The author(s) declared no potential conflicts of interest concerning the research, authorship, and/or publication of this article. 


\section{References}

1. S. Kaynak, B. Kaynak, A. Özmen. "A software tool development study for solar energy potential analysis", Energy and Buildings, Vol. 162(1), 2018, pp:134-143 . https://doi.org/10.1016/j.enbuild.2017.12.033

2. S. M. Maleki, H. Hizam, C. Gomes. "Estimation of Hourly, Daily and Monthly Global Solar Radiation on Inclined Surfaces: Models Re-Visited", Energies, Vol. 10(1), 2017. https://doi.org/ 10.3390/en10010134

3. A. Ibrahim, A. A. El-Sebaii, M. R.I. Ramadan, S. M. El-Broullesy. "Estimation of solar irradiance on tilted surfaces facing south for Tanta, Egypt", International Journal of Sustainable Energy, Vol.1(1),2011, pp:1-10. https://doi.org/10.1080/14786451.2011.601814

4. A.A. El-Sebaii, F.S. Al-Hazmi, A.A. Al-Ghamdi, S.J. Yaghmour. "Global, direct and diffuse solar radiation on horizontal and tilted surfaces in Jeddah, Saudi Arabia", Applied Energy, Vol.87(2), 2010, pp. 568-576. http://doi.org/10.1016/j.apenergy.2009.06.032

5. K. N. Liou, An Introduction to Atmospheric Radiation,. San Diego, CA: Academic Press. 2002.

6. T. Khatib, A. Mohamed, K. Bin Sopian "A review of solar energy modeling techniques", Renewable and Sustainable Energy Reviews, 16(5), 2012. http://doi.org/10.1016/j.rser.2012.01.064

7. B. Subramanian, S. Chinnappanadar, M. Jayachandran "Photoelectrochemical characteristics of brush plated tin sulfide thin films", Solar Energy Materials and Solar Cells,79(1), 2003, pp:57-65. http://doi.org/10.1016/S0927-0248(02)00366-5

8. Ö. Ayvazoğluyüksel, Ü. Başaran Filik. "Estimation methods of global solar radiation, cell temperature and solar power forecasting: A review and case study in Eskişehir", Renewable and Sustainable Energy Reviews, Vol. 91, 2018, pp: 639-653. http://doi.org/ 10.1016/j.rser.2018.03.084

9. I.D.Ibrahim, Y.Hamam, "A review on Africa energy supply through renewable energy production: Nigeria, Cameroon, Ghana and South Africa as a case study", Energy Strategy Reviews, Vol. 38, 2021, pp:100740. https://doi.org/10.1016/j.esr.2021.100740

10. S. Shafiei, R.A. Salim "Non-renewable and renewable energy consumption and CO2 emissions in OECD countries: a comparative analysis", Energy Pol., 66 (2014), pp. 547-556. http://doi.org/10.1016/j.enpol.2013.10.064

11. J. Cousse, Müller-Fried bergstrasse, St. Gallen, "Still in love with solar energy? Installation size, affect, and the social acceptance of renewable energy technologies", Renewable and Sustainable Energy Reviews, 2021, vol. 145, issue C. http://doi.org/10.1016/j.rser.2021.111107

12. G. N. Tiwari, A. Tiwari, and Shyam, "Handbook of Solar energy". pages 2-20, 2016.

13. R. J. Fanchi, "Solar Energy", Energy Technology and Directions for the Future, Pages 193-217, 2004.

14. M. Hissoufa, A. Charefa, "Performance of a photovoltaic-thermal solar collector using two types of working fluids at different fluid channels geometry.". Renewable Energy, Volume 162, December 2020, Pages 1723-1734. http://doi.org/10.1016/j.renene.2020.09.097

15. S. Gorjian and A. Shukla, "Photovoltaic Solar Energy Conversion - Technologies, Applications and Environmental Impacts", Academic Press , 2020. https://doi.org/10.1016/C2018-0-05265-2

16. A. Denzer, "The solar House pioneering sustainable Design". 2013.

17. A. Roux, A. Shanker,“ Net metering and PV self-consumption in emerging countries” International Energy Agency, 2018.

18. A.M. Humada, M. Hojabri, H.M. Hamada, F.B. Samsuri, M.N. Ahmed, "Performance evaluation of two PV technologies (c-Si and CIS) for building integrated photovoltaic based on tropical climate condition: A case study in Malaysia", Energy Build. 119 (2016) 233-241. https://doi.org/10.1016/j.enbuild.2016.03.052

19. C. Mokhtara, B. Negrou, N. Settou, "Optimal design of grid-connected rooftop PV systems: An overview and a new approach with application to educational buildings in arid climates", Sustainable Energy Technologies and Assessments, Vol. 47, October 2021, 101468. https://doi.org/10.1016/j.seta.2021.101468

20. S. Gorjian, and A. Shukla, "Photovoltaic solar Energy conversion", Chapter 5, pp: 117-145,2020.

21. N. Anang, S.N.A. Syd Nur Azman, W.M.W. Muda, "Performance analysis of a grid-connected rooftop solar PV system in Kuala Terengganu, Malaysia", Energy \& Buildings, 2021. Volume 248, 1 October 2021, 111182. https://doi.org/10.1016/j.enbuild.2021.111182

22. D. Revati, E. Natarajan, "I-V and P-V characteristics analysis of a photovoltaic module by different methods using Matlab software", Materials Today: Proceedings 33, 25 April 2020. http://doi.org/10.1016/j.matpr.2020.04.043 
23. I. H. Mahammed, A. Hadj Arab, S. berrah, Y. Bakelli, "Outdoor study of partial shading effects on different PV modules technologies", Energy Procedia 141, December 2017, pp:81-85. http://doi.org/ 10.1016/j.egypro.2017.11.016.

24. T.M. Clack Christopher, S. Qvist, Jay Apt, et al. "Evaluation of a proposal for reliable low-cost grid power with $100 \%$ wind, water, and solar" Proceedings of the National Academy of Sciences 114(26), June 2017, pp:1-6. http://doi.org/10.1073/pnas.1610381114

25. G. Ansanelli, G. Fiorentino, M. Tammaro, A. Zucaro, "A Life Cycle Assessment of a recovery process from End-of-Life Photovoltaic Panels", Applied Energy, Vol. 290, 15 May 2021, 116727. https://doi.org/10.1016/j.apenergy.2021.116727

26. J. Paul, M. Elliott, "Nanotechnology for Energy and Water", Springer Science and Business Media LLC, 2018.

27. IEC61724-1 "Photovoltaic system performance part 1: Monitoring", International Electrotechnical commission. IEC, 2017.

28. T. Dewi, P. Risma, Y. Oktarina. "A Review of Factors Affecting the Efficiency and Output of a PV System Applied in Tropical Climate", IOP Conference Series: Earth and Environmental Science,258,2019. http://doi.org/ 10.1088/1755-1315/258/1/012039

29. J.D. Bastidas-Rodriguez, G. Petrone, C.A. Ramos-Paja, G. Spagnuolo "A genetic algorithm for identifying the single diode model parameters of a photovoltaic panel", Math Comput Simul, 131 (2017), pp. 38-54. https://doi.org/10.1016/j.matcom.2015.10.008

30. L. S. Kothari, P. C. Mathur, A. Kapoor, P. Saxena, R. P. Sharma. "Determination of optimum load for a solar cell", Journal of Applied Physics 54, 1983, 6068. https://doi.org/10.1063/1.332830

31. M. Hatti,"Artificial Intelligence and Renewables Towards an Energy Transition", Springer Science and Business Media LLC, 2021.

32. M.A..Hamdy, "The effect of the diode ideality factor on the experimental determination of series resistance of solar cells", Solar Cells, Volume 20, Issue 2, March 1987, Pages 119-126. https://doi.org/10.1016/03796787(87)90036-6

33. G. T. Odai, GodloveLaryea, "Comparative study of the performance of solar photovoltaic module technologies installed in Kumasi, Ghana, in Sub-Saharan Africa", Scientific African 13(1), 28 July 2021, p:e00877. http://doi.org/10.1016/j.sciaf.2021.e00877

34. https://www.jinkosolar.com/sales.

35. R. Kumar, R. Verma, R. K. Aggarwal. "Empirical model for the estimation of global solar radiation for Indian locations", International Journal of Ambient Energy, $2018.42(2): 1-21$. http://doi.org/10.1080/01430750.2018.1525588

36. S. Abubakar, S. Umaru, M.U. Kaisan, U.A. Umar, B. Ashok, K. Nanthagopal. "Development and Performance Comparison of Mixed-Mode Solar Crop Dryers with and without Thermal Storage", Renewable Energy, 2018, Vol. (128). http://doi.org/10.1016/j.renene.2018.05.049

37. K. Khouzam, L. Khouzam. "Optimum matching of direct-coupled electromechanical loads to a photovoltaic generator", IEEE Transactions on Energy Conversion, 1993.

38. A. Al-Subhi. "Parameters estimation of photovoltaic cells using simple and efficient mathematical models", Solar energy, Vol. 209, October 2020, Pages 245-257.https://doi.org/10.1016/j.solener.2020.08.079

39. D. L. King, J. K. Dudley, and W. E. Boyson, "PVSIM: a simulation program for photovoltaic cells, modules and arrays," in Proceedings of the 25th IEEE PV Specialists Conference, pp. 1295-1297, 1996.

40. E. L. Meyer." Extraction of Saturation Current and Ideality Factor from Measuring Voc and Isc of Photovoltaic Modules" International Journal of Photoenergy Volume 2017, Article ID 8479487, 9 pages, Published 19 December 2017. https://doi.org/10.1155/2017/8479487

41. T. A. Chandel, M. Y. Yasin, M. A. Mallick, "Modeling and simulation of photovoltaic cell using single diode solar cell and double diode solar cell model", August 2019, International Journal of Innovative Technology and Exploring Engineering 8(10). http://doi.org/10.35940/ijitee.J8863.0881019

42. A. Ibrahim, MRI Ramadan, S Aboul-Enein, A A. ElSebaii, SM El-Broullesy, Short Circuit Current Isc as a Real Non-Destructive Diagnostic Tool of a Photovoltaic Modules Performance, International Journal of Renewable Energy Research 1(3), 2011, pp:553-559. 
43. A. Ibrahim, MRI Ramadan, S Aboul-Enein, A A. ElSebaii, SM El-Broullesy, Annual Performance of Solar Modules with Tilting Angle Facing South and Sun Tracking in Tanta, Egypt, International Journal of Renewable Energy Research, Vol. 1, No. 1, , 2011, pp.26-40.

44. A. Ibrahim, MRI Ramadan, S Aboul-Enein, A A. ElSebaii, SM El-Broullesy, Outdoor and indoor measurements of the electrical characteristics of a mono-crystalline silicon solar module, Vol.32(3), 2013, pp:137152. https://doi.org/10.1080/14786451.2011.604418 